\title{
Role of Integrated Nutrient Management for Sustainable Maize Production
}

\author{
Almaz Meseret Gezahegn \\ Agronomy and Crop Physiology Research Program, Ethiopian Institute of Agricultural Research, \\ Debre Zeit Agricultural Research Center, 32, Debre Zeit, Addis Ababa, Ethiopia \\ Correspondence should be addressed to Almaz Meseret Gezahegn; almimeseret@gmail.com
}

Received 24 March 2021; Accepted 19 May 2021; Published 28 May 2021

Academic Editor: Allen Barker

Copyright () 2021 Almaz Meseret Gezahegn. This is an open access article distributed under the Creative Commons Attribution License, which permits unrestricted use, distribution, and reproduction in any medium, provided the original work is properly cited.

\begin{abstract}
Boosting crop productivity can be attained through the application of inorganic fertilizer; however, safeguarding the environment for future generations is overbearing especially for continuous increase in the world population. Sustainable crop productivity might be attained through the judicious use of both organic and inorganic fertilizers. The substitution of parts of inorganic fertilizers with organic fertilizer could maintain and sustain soil productivity and improve crop productivity. This paper has reviewed the past research work carried out by various scientists. A comprehensive literature review revealed that integrated nutrient management enhances maize yield, nutrient uptake, and economic return compared with the sole application of organic and inorganic fertilizers.
\end{abstract}

\section{Introduction}

Maize (Zea mays L.) is one of the most significant cereal crops which served as a staple food for greater than 900 million peoples in developing countries. It provided as a source of raw material for the production of food sweeteners, alcoholic beverages, protein, oil, and starch, as well as a fuel source. Due to its wider adaptability, the crop is growing across a wide range of climatic conditions of the world $[1,2]$. Ethiopia is the fifth leading producer of maize in the continent and smallholder farmers accounted for $94 \%$ of its production. It ranks 1 st in total production and 2 nd in area coverage after tef [3]. Maize offers $16.7 \%$ of per capita calorie intake nationwide since maize is the inexpensive source of caloric intake in Ethiopia.

Maize is commonly called the queen of cereals thanks to high genetic yield potentials compared to the other cereals [4]. Considering its genetic potentials of yield and fast growth habits, maize is an extremely nutrient exhaustive crop. Maize requires more $\mathrm{N}$ and $\mathrm{P}$ than other essential elements for the development of all growth stages. To produce high yield and sustain soil fertility, essential nutrient elements ought to be provided in an appropriate amount. Balanced application of plant nutrients through the integration of organic and inorganic fertilizers has been proved to enhance maize yield and soil fertility [5]. Integrated nutrient management resulted in synergistic effects and improved synchronization of nutrient uptake and release by crops [6] resulted in higher yields, especially when the rates of chemical fertilizers used are relatively low as is the case of most smallholder farmers in a developing country [7]. Integrated application of inorganic fertilizers with different sources of organic manures in different amounts has significant benefits to enhance maize productivity, improve nutrient uptake by plants, and maintain soil nutrient status in maize-based cropping systems [5]. Therefore, this review article aims to discuss the different components of integrated nutrient management and their effect on sustainable maize crop production.

\section{Concepts of Integrated Nutrient Management}

Integrated nutrient management (INM) is a method that helps to sustain agricultural production and protect the environment for future generations. It may be defined as the 
application of soil fertility management practices that maximize fertilizer and organic resource use efficiency to enhance crop production [8]. This practice includes the judicious use of appropriate types of chemical fertilizers and organic resources [9]. It combines both organic and inorganic nutrient sources to achieve higher crop productivity, prevents soil degradation, and improves soil-water infiltration, thus helping to meet future food supply [10]. Sustainable food security needs a balance between increasing crop productivity and environmental sustainability. Neither nutrient deficiency nor surpluses can threaten this balance.

The three main components of INM as defined by FAO [11] are as follows:

(i) Maintaining or improving the productivity of soil through balanced fertilizers, or by combining organic and inorganic fertilizers

(ii) Improving stocks of plant nutrients in the soils

(iii) Increasing the efficiency of plant nutrients, hence, limiting losses to the environment

Therefore, INM aims to maintain or adjust soil fertility and supply plant nutrient to an optimal level for sustaining crop productivity through the integration of the benefit of all possible sources of plant nutrients [12]. Integrated nutrient management is currently considered as an approach that helps smallholder farmers to alleviate many issues such as poverty and food insecurity through enhancing the amount and quality of food and improving soil fertility.

\section{Effect of Chemical Fertilizer on Maize Production}

Chemical fertilizer is a material that is applied to the soil to provide one or more essential elements for plant growth and productivity. Nitrogen, potassium, and phosphorus are the three major elements and magnesium, calcium, sulfur, and other elements such as boron, manganese, iron, zinc, copper, and molybdenum are the secondary elements. Fertilizers improve soil fertility or substitute the mineral elements taken from the soil by harvesting, erosion, grazing, or leaching. Chemical fertilizers are the most effective way to improve soil nutrient depletion, giving high $\mathrm{N}$ and $\mathrm{P}$ contents that are readily available to the crop, and thus improving livelihoods of the farmers [13, 14]. This is because the nutrients in chemical fertilizers are available immediately for plant uptake [15]. The application of adequate fertilizers improved nutrient concentrations in plant tissue and increased crop yield [16]. Obidiebube et al. [17] reported that the application of chemical fertilizer significantly increased the growth, physiological traits, and yield component of maize. Dubey et al. [18] also reported that the application of recommended 100\% NPK fertilizers significantly increased crop yield and improved the available $\mathrm{P}, \mathrm{K}$, and total $\mathrm{N}$ as compared to the initial value thereby indicating a significant contribution towards sustaining the soil health.

Although higher crop yields can be achieved through the judicious use of chemical fertilizers, the adoption has been poor in Africa [19]. Efforts to introduce chemical fertilizer technology to African smallholder farmers have been met with limited success, even with input subsidies and credit systems [20]. According to Stoorvogel et al. [21] estimation in sub-Saharan Africa (SSA) from about 200 million hectares of cultivated land, an average of $660 \mathrm{~kg}$ of N/ha, $450 \mathrm{~kg}$ of K/ ha, and $75 \mathrm{~kg}$ of $\mathrm{P} / \mathrm{ha}$ have been lost since the $1960 \mathrm{~s}$. However, chemical fertilizer use is estimated at $8 \mathrm{~kg} \cdot \mathrm{ha}^{-1}$, which is only $10 \%$ of the world average due to high cost [22].

On the other hand, the intensive use of chemical fertilizer (especially $\mathrm{N}$ fertilizer) can result in detrimental changes in foods and negative effects on atmospheric and aquatic environments [23]. Mahajan et al. [24] and Satyanarayana et al. [25] reported that the nutrients provided through inorganic sources enhanced yield initially but led to unsustainable productivity over the years. Bokhtiar and Sakurai [26] stated that the use of imbalanced nutrients through chemical fertilizer in continuous cropping leads to an imbalance of nutrients in the soil, leaching of $\mathrm{N}$, contamination of water resources, decimation of microorganisms and friendly insects, crop vulnerability to disease outbreak, soil acidification or alkalization, or decreased soil fertility thus bringing permanent loss to the whole system. This is due to their susceptibility to losses in gaseous forms or by leaching when applied at a wrong time or in an excess amount beyond the plant demand [15]. The negative effects of inorganic fertilizer coupled with their high costs have incited the interest for the utilization of organic fertilizer as a source of nutrients [27].

\section{Effect of Organic Fertilizer on Maize Production}

Organic fertilizers also referred to as organic sources are defined as those organic resources that are used in agriculture as a recycled or external input to produce crops for both subsistence and commercial purposes [28]. Animal manure, crop residues, compost, green manure, relay or intercropping of legumes (dual-purpose legumes), and biomass resulting from short- to long-term fallows are among the most promising organic sources [28]. These sources have been recognized as alternative nutrient sources for the smallholder farmers to fertilize their soils as their socioeconomic limitations prevent them from using chemical fertilizers correctly [29].

Organic manures affect the availability of nutrients by adding nutrients, through the mineralization-immobilization process, as a source of energy for microbial activities or as precursors to soil organic matter, and by lessening $\mathrm{P}$ fixation in the soil [30]. Organic manure improves the overall physical characteristics of the soil and soil organic matter together with the major and minor organic nutrients and prevents physical compaction of soil, improves soil aeration, and prevents leaching losses. According to Verma J. P. and Verma R. [31], the collective interaction of the nutrient components in organic fertilizer incorporates the soil with the complete range of nutrients within a comparatively short time, and their effects last longer for the current crop to benefit directly. Agriculture lacking organic 
manures/crop residues has resulted in a lessening of biological and physicochemical properties of the soil [31].

Jolokhava et al. [32] reported that the grain yield of maize from two different types of organic fertilizers reached $70 \%$ of the yields attained with chemical fertilizers. This result is promising for future improvement of organic cereal crop production in the area. Similarly, the study conducted by Soro et al. [33] showed a positive influence of manure on the growth and development of maize crops and emphasized the opportunity of improving maize productivity and production in Daloa region by using poultry manure (PM). The result further revealed that grain yield is significantly boosted by the addition of manure and the highest grain yield was obtained at the rate of $7 \mathrm{t} \cdot \mathrm{ha}^{-1}$ when PM was wind stored for six days. Similarly, Dikinya and Mufwanzala [34] reported that the application of poultry manure increased crop production and soil fertility.

Jjagwe et al. [35] reported that maize growth parameters and yields were all significantly increased $(p<0.05)$ with an application of both organic and inorganic fertilizers when compared with the control. The authors further confirmed that vermicomposting was the most economically feasible manure treatment method due to low operational costs and higher returns on investment that are complemented with the production of chicken fodder (earthworm biomass) and they recommended farmers to produce a fertilizer that increases maize yields with a guarantee of economic returns.

\section{Effect of Integrated Nutrient Management on Maize Production}

High and stable yield could be attained through reasonable and balanced fertilization of organic and inorganic fertilizers [36]. Several studies showed INM significantly improved yield and yield traits of maize [37]. The combined use of poultry manure and chemical fertilizer was more effective in increasing nutrient availability and maize performance than the sole application of any of the fertilizers [38]. Similarly, Ayoola and Adeniyan [39] reported higher yields in the combined application of poultry manure and chemical fertilizer than the sole application of poultry manure and control; however, the yield in a combination of organic and inorganic was not significantly different from sole inorganic fertilizer. Khan et al. [40] also found higher plant height, 1000 grain weight, LAI, and yield of maize in the combined application of 20 tons $\mathrm{ha}^{-1} \mathrm{FYM}$ with $60 \mathrm{~kg} \cdot \mathrm{N} \cdot \mathrm{ha}^{-1}$ inorganic fertilizer than the sole application of each fertilizer. The same authors recommended the combined application of organic manure with the reduced amount of inorganic fertilizer for sustainable crop production.

Thavaprakaash et al. [41] found that a combined application of $50 \%$ NPK with poultry manure and biofertilizers (Azospirillum + phosphor bacteria) gave taller plants (183.1 and $158.4 \mathrm{~cm}$ ) and higher LAI (3.47 and 2.75). The more rapid growth observed in the application of poultry manure and goat manure was due to the faster release of nutrients from the goat and poultry manures as compared to FYM. The same authors indicated the positive effect of INM practices on yield attributes of baby corn and conclude that
INM $\quad$ practices $\quad(50 \% \quad \mathrm{NPK}+$ poultry/goat manure + Azospirillum + phosphobacteria) could produce the maximum yield of baby corn.

The application of poultry manure with recommended NPK fertilizer gave higher grain $\left(5.8 \mathrm{t} \cdot \mathrm{ha}^{-1}\right)$ and green matter $\left(7.44 \mathrm{t}^{\mathrm{h}} \mathrm{ha}^{-1}\right)$ yields than vermicompost with recommended NPK fertilizer and control treatments, and the grain yield with poultry manure, vermicompost, and farmyard manure increased by 33,16 , and $14 \%$ over control, respectively [42]. Negassa et al. [43] demonstrated that the integrated use of farmyard manure (FYM), compost, and bone meal with a low level of NP fertilizers gave a comparable maize grain yield as the yield obtained under the recommended rate of NP fertilizers $\left(110 / 20 \mathrm{~kg} \cdot \mathrm{ha}^{-1}\right)$ in Western Ethiopia. Zerihun et al. [44] also reported that the combined use of organic and inorganic fertilizers increased the yield of maize and soybean in the intercropping system. The integrated use of NP fertilizer $(55: 23 \mathrm{~kg} / \mathrm{ha})$ and FYM $\left(8 \mathrm{t} \cdot \mathrm{ha}^{-1}\right)$ was more profitable with some additional soybean yield than the sole application of either fertilizer in maize/ soybean intercropping system.

Khaliq et al. [45] revealed that the combination of poultry manure $+\mathrm{N}$ fertilizer significantly increased biomass yield, grain yield, and chemical properties of soil followed by high $\mathrm{N}$ fertilizer treatment in two maize hybrids. Shivakumar and Ahlawat [46] also found that the combined application of crop residues and FYM along with $5 \mathrm{~kg}$ zinc/ha and $100 \%$ recommended dose of fertilizer gave significantly higher growth and yield of soybean. The combined application of $75 \%$ NPK with phosphocompost or poultry manure or farmyard manure in sorghum and soybean crops and application of $75 \%$ NPK fertilizer in wheat crop gave significantly greater grain yields compared to organic and control and saved 25\% NPK fertilizer [47]. The same author reported that the number of grains per spike, dry matter accumulation, straw yield, grain yield, and NPK uptake of wheat were higher in a combination of organic and inorganic fertilizers than inorganic fertilizer alone. A field experiment conducted by Panwar [48] also showed that the growth, yield attributes, and economics of maize were optimum when $50 \%$ of the recommended dose of NPK was substituted by farmyard manure. Baes on Tetarwal et al. [49] recommended dose of fertilizer $(40-15 \mathrm{~kg} \cdot \mathrm{N}-\mathrm{P} / \mathrm{ha})+\mathrm{FYM}$ $10 \mathrm{t} /$ ha produced higher plant height, dry matter, number of cobs/plant, number of grains/cob, grain, and biological yields of maize.

Ravi et al. [50] study showed that higher plant height $(187.8 \mathrm{~cm})$, leaf area index (4.7), total dry matter production (309.4 g/plant), weight per cob $(122.2 \mathrm{~g})$, cob length $(15.8 \mathrm{~cm})$, cob girth $(11.52 \mathrm{~cm})$, and seed index $(29.1 \mathrm{~g})$ in maize were associated with the application of FYM $10 \mathrm{t} /$ ha +100 percent recommended dose of fertilizer (150:75: $37.5 \mathrm{~kg} \mathrm{NPK} / \mathrm{ha}+25 \mathrm{~kg} \mathrm{ZnSO} / \mathrm{ha})$. Similarly, Samsul et al. [51] reported that application of 75\% recommended dose of fertilizer (90:45:45 NPK kg/ha)+vermicompost @2 t/ha gave the tallest plant $(240$ and $219 \mathrm{~cm})$, higher leaf area index, dry matter production, tasseling and silking, and effective number of cobs per plant at Tarai region of West Bengal. 


\section{Effect of Integrated Nutrient Management on Nutrient Uptake of Maize}

A combined application of organic and inorganic appears to be an ideal method to meet nutrient requirements of crops rather than a sole application of either source. The combined application of fertilizers and manures increased the nutrient uptake of the plants [9]. Prasad et al. [52] found higher NPK uptake of maize crop in a combination of organic and inorganic fertilizers compared to treatment where a full dose of NPK was applied as urea, single superphosphate, and muriate of potash. Ghosh et al. [53] also reported that combined use of organic manure and NPK fertilizers was significantly increased in NPK uptake of wheat.

Makinde and Ayoola [54] reported that nutrient uptake in the sole application of inorganic fertilizer was better than the sole use of organic fertilizer, which gave similar values with unfertilized plants due to the slow release of nutrients. Conversely, combined use of organic and inorganic fertilizers gave higher $\mathrm{N}$ and $\mathrm{K}$ values compared to the sole application of either fertilizer. Since organic manures supply all essential nutrients which play an important role in crop growth and hence finally increase the yield with balanced nutrition, higher nutrient uptake by the crops can result in higher yield. Quansah [55] also reported higher NPK uptake in the combined application of poultry manure $(60 \mathrm{~kg} / \mathrm{ha} \mathrm{N})$ with NPK (60-40-40 kg/ha) fertilizer than the sole application of either fertilizer.

Vidyavathi et al. [56] found significantly higher uptake of $\mathrm{N}, \mathrm{P}$, and $\mathrm{K}$ under a combination of organic and inorganic fertilizers compared to the sole application of either fertilizer. The response of crops to the combined application of both fertilizers is due to the higher availability of $\mathrm{N}, \mathrm{P}$, and $\mathrm{K}$ in the soil reservoir besides the additional amount of nutrients provided by FYM and NPK fertilizers. This was attributed to a steady supply of $\mathrm{N}, \mathrm{P}$, and $\mathrm{K}$ throughout the growing season. Similarly, Prajapat et al. [57] reported a significantly maximum total uptake of $\mathrm{N}$ and $\mathrm{P}$ of soybean at $25 \%$ recommended inorganic fertilizer $+50 \%$ recommended FYM + biofertilizers over sole application of inorganic fertilizer and FYM.

Tetarwal et al. [49] reported that significant buildup of organic carbon $(0.74 \%)$, available $\mathrm{N}(316.0 \mathrm{~kg} / \mathrm{ha})$, available $\mathrm{P}(10.8 \mathrm{~kg} / \mathrm{ha})$, and $\mathrm{Zn}$ uptake were observed with the application of the recommended dose of fertilizer $(40-15 \mathrm{~kg}$ $\mathrm{N}-\mathrm{P} / \mathrm{ha}$ ) + FYM $10 \mathrm{t} / \mathrm{ha}$. Similarly, Almaz et al. [58] reported that integrated application of $50 \% \mathrm{NPK}+50 \%$ poultry manure increased nutrient $(\mathrm{N}, \mathrm{P}$, and $\mathrm{K})$ uptake of maize over sole poultry manure and sole inorganic fertilizer.

\section{Economic Importance of Integrated Nutrient Management}

Maintenance of soil fertility at the economic optimum level with an appropriate cropping system and affordable fertilizer rate is essential for sustainable crop production. Integrated nutrient management systems ensure inbuilt capacity to maintain and improve soil health and fertility leading to sustained crop production and lower variability of crop yield. This resulted in stable yield, increased income, and sustainable agriculture. The economic importance of integrated nutrient management has been reported by previous researchers [59-61].

The economic analysis done by Jinwei and Lianren [62] showed that an integrated application of organic and chemical fertilizers reduced the cost of fertilizer compared with the sole application of either fertilizer. Saleem et al. [63] also reported the highest net benefit (Rs. 78,419.66 ha ${ }^{-1}$ ) of monocropped maize with the combined use of $50 \%$ poultry manure $+50 \% \mathrm{PK}+$ inoculation compared to the sole application of either fertilizer. Singh and Agarwal [64] noted that the combined application of $10 \mathrm{t} / \mathrm{ha}$ FYM and $180 \mathrm{~kg} \mathrm{~N} /$ ha gave higher net returns of Rs. $12,519 \mathrm{ha}^{-1}$ with the highest $\mathrm{B}: \mathrm{C}$ ratio of 2.13 , respectively. The combined application of $5 \mathrm{t} / \mathrm{ha}$ crop residues and FYM along with $5 \mathrm{~kg} /$ ha zinc gave higher yield and net returns from soybean-wheat cropping system than the sole use of either organic or inorganic fertilizers [64]. Similarly, Ali et al. [65] indicated that treatments that received a combined application of organic manure and inorganic fertilizer produced benefit: a cost of greater than 3.0, indicating the profitability of the system. Pathan and Kamble [66] also reported highest gross returns, net returns, and benefit: cost ratio (Rs. 191,981, Rs.101,815 ha and of 2.13, respectively) of sorghum + cowpea-lucerne forage cropping system in the combination of FYM $(25 \% \quad \mathrm{~N})+50 \%$ NPK fertilizer + biofertilizers. Similarly, Subbarayappa et al. [67] revealed that integrated application of $100 \%$ NPK + FYM led to significantly higher net returns (Rs. 22,372/ha), higher benefit: cost (B:C) ratio (4.22), and gross returns (Rs. $29,306 \mathrm{ha}^{-1}$ ) in cowpea.

Panwar [48] found that the maize equivalent yield, net return, and $\mathrm{B}: \mathrm{C}$ ratio for maize-mustard cropping system was higher under $50 \%$ NPK $+50 \%$ farmyard manure than under $25 \%$ of NPK substitution through farmyard manure $+75 \%$ NPK through inorganic fertilizer. Similarly, Lingaraju et al. [68] reported that the treatment of $7.5 \mathrm{t} / \mathrm{ha}$ FYM and 100 percent RDF (100:50:25 N, $\mathrm{P}_{2} \mathrm{O}_{5}$ and $\mathrm{K}_{2} \mathrm{O} \mathrm{kg} /$ ha) resulted in significantly higher gross return (Rs. 69059/ ha) and net return (Rs. 51659/ha) which were on par with vermicompost @2.5t/ha +100 percent RDF concerning gross returns (66513). The benefit: cost ratio was markedly higher with poultry manure @1.0 t/ha + 100 percent RDF (4.48).

\section{Conclusion}

Soil fertility depletion is the fundamental biophysical cause of low crop production in developing countries. To maintain soil fertility, the use of inorganic fertilizers is important. Nevertheless, high cost of inorganic fertilizers combined with the low income of resource-poor farmers in developing countries is the main challenge using inorganic fertilizer. The use of organic manures can maintain soil organic matter and provide balanced nutrients to the present crop and leave an extensive residual nutrient on the subsequent crops in a cropping system. Retention of crop residue on the cropland has also a positive effect on soil organic matter and crop 
production. However, the amount of organic sources required is huge as their nutrient content is low. The integration of different sources of nutrients has been proven to be documented success in a different part of the world than the sole use of either inorganic fertilizers or organic manures. The system is not only boosting crop productivity but also maintains and sustains soil productivity and also a costeffective practice for developing countries.

\section{Data Availability}

No data were used to support this study.

\section{Conflicts of Interest}

The author declares that there are no conflicts of interest.

\section{References}

[1] A. D. Hartkamp, Maize Production Environments Revisited: A GIS-Based Approach, CIMMYT, Mexico City, Mexico, 2001.

[2] Amanullah, M. J. Hassan, K. Nawab, and A. Ali, "Response of specific leaf area (SLA), leaf area index (LAI) and leaf area ratio (LAR) of maize (Zea mays L.) to plant density, rate and timing of nitrogen application," World Applied Sciences Journal, vol. 2, no. 3, pp. 235-243, 2007.

[3] CSA, Agricultural Sample Survey 2016/2017: Report on Area and Production of Major Crops (Private Peasant Holdings, "Meher" season). Statistical Bulletin, Vol. 1, CSA, Addis Ababa, Ethiopia, 2017.

[4] R. L. Kannan, M. Dhivya, D. Abinaya, R. L. Krishna, and S. Krishnakumar, "Effect of integrated nutrient management on soil fertility and productivity in maize," Bulletin of Environment, Pharmacology and Life Sciences, vol. 2, no. 8, pp. 61-67, 2013.

[5] M. G. Almaz, R. A. Halim, and M. Y. Martini, "Effect of combined application of poultry manure and inorganic fertiliser on yield and yield components of maize intercropped with soybean," Pertanika Journal of Tropical Agricultural Science, vol. 40, no. 1, pp. 173-183, 2017.

[6] C. A. Palm, R. J. K. Myers, and S. M. Nandwa, "Organicinorganic nutrient interactions in soil fertility replenishment," Replenishing Soil Fertility in Africa, vol. 51, pp. 193-218, 1997.

[7] J. J. Kapkiyai, N. K. Karanja, P. Woomer, and J. N. Qureshi, "Soil organic carbon fractions in a long-term experiment and the potential for their use as a diagnostic assays in highland farming systems of central Kenya," African Crop Science Journal, vol. 6, pp. 19-28, 1998.

[8] N. Sanginga and P. L. Woomer, Integrated Soil Fertility Management in Africa: Principles, Practices, and Developmental Process, CIAT, Cali, Colombia, 2009.

[9] O. Adeniyan and S. Ojeniyi, "Comparative effectiveness of different levels of poultry manure with NPK fertilizer on residual soil fertility, nutrient uptake and yield of maize," Moor Journal of Agricultural Research, vol. 4, no. 2, pp. 191197, 2005.

[10] C. Chen, M. Westcott, K. Neill, D. Wichman, and M. Knox, "Row configuration and nitrogen application for barley-pea intercropping in Montana," Agronomy Journal, vol. 96, no. 6, pp. 1730-1738, 2004.

[11] FAO, Guide to Efficient Plant Nutrient Management, Rome: Land and Water Development Division, Food and Agricultural
Organization of the United Nation, Quebec City, Canada, 1998.

[12] P. Gruhn, F. Goletti, and M. Yudelman, Integrated Nutrient Management, Soil Fertility, and Sustainable Agriculture: Current Issues and Future Challenges, International Food Policy Research Institute, Washington, DC, USA, 2000.

[13] A. Bationo, J. Kihara, B. Vanlauwe, B. Waswa, and J. Kimetu, "Soil organic carbon dynamics, functions and management in West African agro-ecosystems," Agricultural Systems, vol. 94, no. 1, pp. 13-25, 2007.

[14] E. K. Bünemann, D. A. Bossio, P. C. Smithson, E. Frossard, and A. Oberson, "Microbial community composition and substrate use in a highly weathered soil as affected by crop rotation and P fertilization," Soil Biology and Biochemistry, vol. 36, no. 6, pp. 889-901, 2004.

[15] J. Nyamangara, M. Piha, and K. Giller, "Effect of combined cattle manure and mineral nitrogen on maize $\mathrm{N}$ uptake and grain yield," African Crop Science Journal, vol. 11, no. 4, pp. 389-300, 2004.

[16] J. A. Adediran, L. B. Taiwo, M. O. Akande, R. A. Sobulo, and O. J. Idowu, "Application of organic and inorganic fertilizer for sustainable maize and cowpea yields in Nigeria," Journal of Plant Nutrition, vol. 27, no. 7, pp. 1163-1181, 2005.

[17] E. Obidiebube, U. Achebe, S. Akparobi, and P. Kator, "Effect of different levels of NPK $(15: 15: 15)$ on the growth and yield of maize in rainforest agro-ecological zone," International Journal of Agricultural Science, vol. 2, no. 12, pp. 1103-1106, 2012.

[18] V. Dubey, A. Patel, A. Shukla, S. Shukla, and S. Singh, "Impact of continuous use of chemical fertilizer," International Journal of Enginering Research \& Developtment, vol. 3, no. 11, pp. 13-16, 2012.

[19] E. W. Crawford, T. S. Jayne, and V. A. Kelly, Alternative Approaches for Promoting Fertilizer Use in Africa, Agriculture \& Rural Development Department, World Bank, Washington, DC, USA, 2006.

[20] M. L. Morris, Fertilizer Use in African Agriculture: Lessons Learned and Good Practice Guidelines, World Bank, Washington DC, USA, 2007.

[21] J. J. Stoorvogel, E. M. A. Smaling, and B. H. Janssen, "Calculating soil nutrient balances in Africa at different scales," Fertilizer Research, vol. 35, no. 3, pp. 227-235, 1993.

[22] P. C. Smithson and K. E. Giller, "Appropriate farm management practices for alleviating $\mathrm{N}$ and $\mathrm{P}$ deficiencies in lownutrient soils of the tropics," Plant and Soil, vol. 245, pp. 169-180, 2002.

[23] H. Hauggaard-Nielsen, S. Mundus, and E. S. Jensen, "Nitrogen dynamics following grain legumes and subsequent catch crops and the effects on succeeding cereal crops," Nutrient Cycling in Agroecosystems, vol. 84, no. 3, pp. 281-291, 2009.

[24] A. Mahajan, R. Bhagat, and R. Gupta, "Integrated nutrient management in sustainable rice-wheat cropping system for food security in India," SAARC Journal of Agriculture, vol. 6, no. 2, pp. 149-163, 2008.

[25] V. Satyanarayana, P. V. Vara Prasad, V. R. K. Murthy, and K. J. Boote, "Influence of integrated use of farmyard manure and inorganic fertilizers on yield and yield components of irrigated lowland rice," Journal of Plant Nutrition, vol. 25, no. 10, pp. 2081-2090, 2002.

[26] S. Bokhtiar and K. Sakurai, "Integrated use of organic manure and chemical fertilizer on growth, yield, and quality of sugarcane in high Ganges river floodplain soils of Bangladesh," 
Communications in Soil Science and Plant Analysis, vol. 36, no. 13-14, pp. 1823-1837, 2005.

[27] T. Tadesse, N. Dechassa, W. Bayu, and S. Gebeyehu, "Effects of farmyard manure and inorganic fertilizer application on soil physico-chemical properties and nutrient balance in rain-fed lowland rice ecosystem," American Journal of Plant Sciences, vol. 4, no. 2, pp. 309-316, 2013.

[28] J. K. Lekasi, "Organic resource management in smallhold agriculture," Organic Resource Management in Kenya: Perspectives and Guidelines, p. 184, Forum for Organic Resource Management and Agricultural Technologies, Nairobi, Kenya, 2003.

[29] A. Bala, A. O. Osunde, and A. J. Odofin, "Organic matter utilisation and the determinants of organic manure use by farmers in the Guinea Savanna zone of Nigeria," Innovations as Key to the Green Revolution in Africa, Springer, Berlin, Germany, pp. 965-974, 2011.

[30] A. Sharma, D. K. Parmar, P. Kumar, Y. Singh, and R. P. Sharma, “Azotobacter soil amendment integrated with cow manure reduces need for NPK fertilizers in sprouting broccoli," International Journal of Vegetable Science, vol. 14, no. 3, pp. 273-285, 2008.

[31] J. P. Verma and R. Verma, Organic Fertilizers and Their Impact on Agricultural Production System, Nova Science Publishers, Inc, Hauppauge, NY, USA, 2012.

[32] T. Jolokhava, N. Kenchiashvili, M. Tarkhnishvili, and G. Ghambashidze, "Effect of organic fertilizers on maize production in Eastern Georgia," in Proceedings of the EGU General Assembly Conference Abstracts, Vienna Austria, April, 2016.

[33] D. Soro, K. Ayolié, F. G. Bi Zro et al., "Impact of organic fertilization on maize (Zea mays L.) production in a ferralitic soil of centre-West cote d'ivoire," Journal of Experimental Biology and Agricultural Sciences, vol. 3, no. 6, pp. 556-565, 2015.

[34] O. Dikinya and N. Mufwanzala, "Chicken manure-enhanced soil fertility and productivity: effects of application rates," Journal of Soil Science and Environmental Management, vol. 1, no. 3, pp. 46-54, 2010.

[35] J. Jjagwe, K. Chelimo, J. Karungi, A. J. Komakech, and J. Lederer, "Comparative performance of organic fertilizers in maize (Zea mays L.) growth, yield, and economic results," Agronomy, vol. 10, no. 1, p. 69, 2020.

[36] B. Kang and V. Balasubramanian, "Long term fertilizer trials on alfisols in West Africa," in Proceedings of the Transactions 14th International Congress of Soil Science, Kyoto, Japan, August 1990.

[37] Y. O. Kemal and M. Abera, "Contribution of integrated nutrient management practices for sustainable crop productivity, nutrient uptake and soil nutrient status in maize based cropping systems," Journal of Nutrients, vol. 2, no. 1, pp. 1-10, 2015.

[38] O. Ayoola and E. Makinde, "Maize growth, yield and soil nutrient changes with $\mathrm{N}$-enriched organic fertilizers," African Journal of Food, Agriculture, Nutrition and Development, vol. 9, no. 1, pp. 580-592, 2009.

[39] O. Ayoola and O. Adeniyan, "Influence of poultry manure and NPK fertilizer on yield and yield components of crops under different cropping systems in south west Nigeria," African Journal of Biotechnology, vol. 5, no. 15, pp. 1386-1392, 2006.

[40] A. Khan, M. T. Jan, K. B. Marwat, and M. Arif, "Organic and inorganic nitrogen treatments effects on plant and yield attributes of maize in a different tillage systems," Pakistan Journal of Botany, vol. 41, no. 1, pp. 99-108, 2009.

[41] N. Thavaprakaash, K. Velayudham, and V. Muthukumar, "Effect of crop geometry, intercropping systems and integrated nutrient management practices on productivity of baby corn (Zea mays L.) based intercropping systems," Research Journal of Agricultural and Biological Sciences, vol. 1, no. 4, pp. 295-302, 2005.

[42] C. Chandrashekara, S. Harlapur, S. Muralikrishna, and G. Girijesh, "Response of maize (Zea mays L.) to organic manures with inorganic fertilizers," Karnataka Journal of Agricultural Sciences, vol. 13, no. 1, pp. 144-146, 2000.

[43] W. Negassa, K. Negisho, and T. Tadesse, "Bone meal and rockphosphate as alternative sources of $\mathrm{P}$ fertilizer for maize production," in Challenges of Land Degradation to Agriculture in Ethiopia, T. Amede and E. Zewdie, Eds., pp. 51-58, Ethiopian Society of Soil Science, Addis Abeba, Ethiopia, 2003.

[44] A. Zerihun, A. Tolera, D. Tusa, and F. K. Kanampiu, "Maize yield response to crop rotation, farmyard manure and inorganic fertilizer application in Western Ethiopia," African Journal of Agricultural Research, vol. 8, no. 46, pp. 5889-5895, 2013.

[45] T. Khaliq, T. Mahmood, J. Kamal, and A. Masood, "Effectiveness of farmyard manure, poultry manure and nitrogen for corn (Zea mays L.) productivity," International Journal of Agriculture and Biology, vol. 2, pp. 260-263, 2004.

[46] B. Shivakumar and I. Ahlawat, "Integrated nutrient management in soybean (Glycine max)-wheat (Triticum aestivum) cropping system," Indian Journal of Agronomy, vol. 53, no. 4, pp. 273-278, 2008.

[47] P. K. Ghosh, K. Ajay, K. K. Bandyopadhyay et al., "Comparative effectiveness of cattle manure, poultry manure, phosphocompost and fertilizer-NPK on three cropping systems in vertisols of semi-arid tropics. II. dry matter yield, nodulation, chlorophyll content and enzyme activity," Bioresource Technology, vol. 95, no. 1, pp. 85-93, 2004.

[48] A. Panwar, "Effect of integrated nutrient management in maize (Zea mays)-mustard (Brassica compestris var toria) cropping system in mid hills altitude," Indian Journal of Agricultural Science, vol. 78, no. 1, pp. 27-31, 2008.

[49] J. P. Tetarwal, B. Ram, and D. S. Meena, "Effect of integrated nutrient management on productivity, profitability, nutrient uptake and soil fertility in rainfed maize (Zea mays)," Indian Journal of Agronomy, vol. 54, no. 4, pp. 373-376, 2011.

[50] N. Ravi, R. Basavarajappa, C. P. Chandrashekar, S. I. Harlapur, M. H. Hosamani, and M. V. Manjunatha, "Effect of integrated nutrient management on growth and yield of quality protien maize," Karnataka Journal of Agriculture Science, vol. 25, no. 3, pp. 395-396, 2012.

[51] H. Samsul, S. P. Partha, and S. Ashok, "Growth attributes, cob yield and economics of maize (Zea mays L.) cultivars as affected by integrated nutrient management under terai region of West Bengal," Indian Journal of Agricultural Research, vol. 46, no. 1, pp. 42-47, 2012.

[52] J. Prasad, S. Karmakar, R. Kumar, and B. Mishra, "Influence of integrated nutrient management on yield and soil properties in maize-wheat cropping system in an alfisol of Jharkhand," Journal of the Indian Society of Soil Science, vol. 58, no. 2, pp. 200-204, 2010.

[53] S. Ghosh, B. Wilson, S. Ghoshal, N. Senapati, and B. Mandal, "Organic amendments influence soil quality and carbon sequestration in the Indo-Gangetic plains of India," Agriculture, Ecosystems \& Environment, vol. 156, pp. 134-141, 2012. 
[54] E. Makinde and O. Ayoola, "Growth, yield and NPK uptake by maize with complementary organic and inorganic fertilizers," African Journal of Food, Agriculture, Nutrition and Development, vol. 10, no. 3, pp. 2204-2217, 2010.

[55] G. W. Quansah, "Effect of organic and inorganic fertilizers and their combinations on the growth and yield of maize in the semi-deciduous forest zone of Ghana," Master's Thesis, Kwame Nkrumah University of Science and Technology, Kumasi, Ghana, 2010.

[56] V. Vidyavathi, G. Dasog, H. Babalad et al., "Influence of nutrient management practices on crop response and economics in different cropping systems in a vertisol," Karnataka Journal of Agricultural Sciences, vol. 24, no. 4, pp. 455-460, 2012.

[57] K. Prajapat, A. Vyas, and S. Dhar, "Effect of cropping systems and nutrient management practices on growth, productivity, economics and nutrient uptake of soybean (Glycine max)," Indian Journal of Agricultural Sciences, vol. 85, no. 9, pp. 229-234, 2015.

[58] M. G. Almaz, R. A. Halim, M. M. Yusoff, and S. A. Wahid, "Effect of incorporation of crop residue and inorganic fertilizer on yield and grain quality of maize," Indian Journal of Agricultural Research, vol. 51, no. 6, pp. 574-579, 2017.

[59] P. Ashoka, B. Pujari, P. Hugar, and B. Desai, "Effect of micronutrients with or without organic manures on yield of baby corn (Zea mays L.-chickpea (Cicer artietinum L.) sequence," Karnataka Journal of Agricultural Sciences, vol. 21, no. 4, pp. 485-487, 2008.

[60] I. Naik and A. Gupta, "Effect of plant density and integrated nutrient management on growth, yield, quality and economics of kale (Brassica oleracea var. acephala) in temperate region," Indian Journal of Agricultural Sciences, vol. 80, no. 1, pp. 80-84, 2010.

[61] E. W. Triplett, K. A. Albrecht, and E. S. Oplinger, "Crop rotation effects on populations of Bradyrhizobium japonicum and Rhizobium meliloti," Soil Biology and Biochemistry, vol. 25, no. 6, pp. 781-784, 1993.

[62] Z. Jinwei and Z. Lianren, "Combined application of organic and inorganic fertilizers on black soil fertility and maize yield," Journal of Northeast Agricultural University (English Edition), vol. 18, no. 2, pp. 24-29, 2011.

[63] R. Saleem, Z. I. Ahmed, M. Ashraf et al., "Response of maizelegume intercropping system to different fertility sources under rainfed conditions," Sarhad Journal of Agriculture, vol. 27, no. 4, pp. 503-511, 2011.

[64] R. Singh and S. Agarwal, "Effect of organic manuring and nitrogen fertilization on productivity, nutrient-use efficiency and economics of wheat (Triticum aestivum)," Indian Journal of Agronomy, vol. 49, no. 1, pp. 49-52, 2004.

[65] M. Ali, M. Islam, and M. Jahiruddin, "Effect of integrated use of organic manures with chemical fertilizers in the rice-rice cropping system and its impact on soil health," Bangladesh Journal of Agricultural Research, vol. 34, no. 1, pp. 81-90, 2009.

[66] S. Pathan and A. Kamble, "Effect of integrated nutrient management on yield sustainability and soil fertility of forage cropping system," Range Management and Agroforestry, vol. 33, no. 2, pp. 151-156, 2012.

[67] C. T. Subbarayappa, S. C. Santhosh, N. Srinivasa, and V. Ramakrishnaparama, "Effect of integrated nutrient management on nutrient uptake and yield of cowpea in southern dry zone soils of Karnataka," Mysore Journal of Agricultural Sciences, vol. 43, pp. 700-704, 2009.

[68] B. S. Lingaraju, K. G. Parameshwarappa, U. K. Hulihalli, and B. Basavaraja, "Effect of organics on productivity and economic feasibility in maize-bengalgram cropping system," Indian Journal of Agricultural Research, vol. 44, no. 3, pp. 211-215, 2010. 